\title{
Quality of English Translation Advertisement in Sukabumi West Java Indonesia
}

\author{
Lusi Susilawati \\ English Letters Department, Muhammadiyah University of Sukabumi \\ Jln. R Syamsuddin, S. H. No. 50 Sukabumi West Java Indonesia, Indonesia \\ Tel: 628-154-875-2495E-mail: lusi@ummi.ac.id
}

\begin{abstract}
Siska Hestiana
English Letter Department, Muhammadiyah University of Sukabumi

Jln. R Syamsuddin, S. H. No. 50 Sukabumi West Java Indonesia, Indonesia

Tel: 628-562-466-4045Ｅ-mail: siskahestiana82@gmail.com
\end{abstract}

Kiki Sri Rezeki

English Letter Department, Muhammadiyah University of Sukabumi

Jln. R Syamsuddin, S. H. No. 50 Sukabumi West Java Indonesia, Indonesia

Tel: 628-231-186-6137Ｅ-mail: kikisriski@gmail.com

Received: October 8, 2017 Accepted: October 17, $2017 \quad$ Published: October 23, 2017

doi:10.5296/ijl.v9i5.12035ＵRL: https://doi.org/10.5296/ijl.v9i5.12035

\begin{abstract}
All countries in ASIA are now facing ASEAN Economic Community (AEC). One of which is by using English in all aspects of the activities. Advertisement (ads) has also a role in facing AEC. Therefore, some companies use English in advertising their products. However its use of English sometime is not accurate and acceptable, therefore the result of its translation is hard to comprehend.

The main target of this research is to identify quality of English Translation Advertisement in Sukabumi Area, West Java Indonesia. The method applied in analyzing it is a descriptive
\end{abstract}


qualitative method and the approach is translation studies. Meanwhile the main theory applied is translation theories from Molina and Albir.

The data are obtained by documenting some English ads which are then analyzed by applying contents analysis method as well as using raters to rate its quality.

The result of the research shows that from 18 techniques of translation, there are only 13 techniques of translation used in the data and it is Literal Technique which is most used by the translators. The percentage is about $19.40 \%$. The use of the techniques results in the low quality of translation. It is shown by the accuracy rate of the translation which is only $38.6 \%$ while its acceptance one is also only 30.8\%. Another result of the research is the method how to translate the ads as well as the revision of some unqualified English translation of ads in Sukabumi.

Keywords: Advertisement, Quality of translation 


\section{MlMacrothink}

\section{Introduction}

In marketing its products, some producers always utilize advertisement (ads) as a tool of their marketing. To attract their consumers, ads is always made as good as possible both from its packaging and from the language. Some of them use English as an international language. However, the translated ads is not fully accurate and acceptable in TL. The main problem in the research is to identify the technique of translation used by translator of ads and how the used techniques have the impact to the quality of translation from the aspects of accuracy and acceptability.

The problem is important to solve in order that the translators of the ads recognize the right technique of translation so that the next ads will be qualified. The similar research has been conducted by Dewi, Ikke (2015) entitled “Creativity n Translating Advertisement”. She focused on some creativity phenomena in translating ads. The research is of certainly different from mine which focuses on the quality of English translation ads.

\subsection{Research Objective}

This research aims at identifying and classifying the use of translation technique and its impacts to the quality of English advertisement translation in Sukabumi as well as finding solution to the unqualified translation.

\subsection{Research Significance}

The result of the research is expected to be beneficial for advertiser particularly English translation ads. Therefore, they will be more cautious in translating especially for using right choice of words and English grammar without reducing its message and criteria of ads. In addition, the research is also expected to be useful either for those involved in translation fields or students of English Department particularly in the courses of translation and interpreting. Moreover, the research is also expected to be the reference for next research related to translation activity.

\subsection{Advertisement}

Ads is one of the media that can be used to promote goods and services. This statement is in accordance with Belch George and Belch Michael (2013 : vi) “Advertising and other types of promotional messages are used to sell products and services as well as to promote causes, market political candidates, and the deal with societal problems such as alcohol and drug abuse”.

\subsection{Role of Ads}

Ads has an important role in marketing a product because it could explain the product in detail. Sumarwan $(2009 ; 117)$ mentions the role of ads as follows:

a. Ads is able to provide the conveyance or awareness for its company and products.

b. When a product has a new feature, ads could well explain the innovation. 
c. Ads offers brochures and informs the address and contact of company more detail and more effective especially for sales representatives.

\subsection{Strategy of Ads}

There must be a strategy to make the ads function as its role. Some experts have offered the strategies, of which is the strategy offered by Ginting (2011: 201):

a. Creating message; the high cost of ads does not determine result, the more creative ads will give good result than the high cost.

b. Changing a large environment; consumers are indoctrinated by ads either at home or at work place.

c. Strategy of message; creating an effective message is deciding what general message that will be delivered to consumers - planning strategy of message.

\subsection{Translation}

Nowadays, translation activity is not only done by translators or by the one who is expert in translation filed, but it is also done by everyone who is able to do it though it is not done by the right way theoretically. The availability of some sophisticated tools like "trans tool" does not assure a work of translation to be a qualified one if the meaning in source language (SL) is not conveyed into target language (TL).

Translation is the activity of transferring message from into TL. The statement is appropriate with some experts of translation both from Indonesia and from abroad. One of which is the statement from Machali (2009: 5) "Translation is an effort of "changing source text with the correspond one on TL.”

\subsection{Technique of Translation}

Technique of translation is a method of a translator in translating text. Molina and Albir (2002: 509 - 511) offers 18 classifications of translation technique applied by a translator. They are:

1. Adaptation.

To replace a ST cultural element with one from the target culture, e.g., to change baseball, for fútbol in a translation into Spanish.

2. Amplification.

To introduce details that are not formulated in the ST: information, explicative paraphrasing, e.g., when translating from Arabic (to Spanish) to add the Muslim month of fasting to the noun Ramadan.

3. Borrowing.

To take a word or expression straight from another language. It can be pure (without any change), e.g., to use the English word lobby in a Spanish text. Or it can also be naturalized (to fit the spelling rules in the TL), e.g., gol, fútbol, líder, mitin.

4. Calque.

Literal translation of a foreign word or phrase; it can be lexical or structural, e.g., the English translation Normal School for the French École normale. 


\section{$\Lambda$ Macrothink}

5. Compensation.

To introduce a source text (ST) element of information or stylistic effect in another place in the target text (TT) because it cannot be reflected in the same place as in the ST.

6. Description.

To replace a term or expression with a description of its form or/and function, e.g., to translate the Italian panettone as traditional Italian cake eaten on New Year's Eve.

7. Discursive Creation.

To establish a temporary equivalence that is totally unpredictable out of context, e.g., the Spanish translation of the film Rumble fish as La ley de la calle.

8. Established equivalent.

To use a term or expression recognized (by dictionaries or language use) as an equivalent in the TL, e.g., to translate the English expression. They are as like as two peas as Se parecen como dos gotas de agua in Spanish.

9. Generalization. To use a more general or neutral term, e.g., to translate the French guichet, fenêtre or devanture, as window in English.

10. Linguistic amplification.

To add linguistic elements. This is often used in consecutive interpreting and dubbing, e.g., to translate the English expression No way into Spanish as De ninguna de las maneras instead of using an expression with the same number of words, En absoluto.

11. Linguistic compression.

To synthesize linguistic elements in the TT. This is often used in simultaneous interpreting and in sub-titling, e.g., to translate the English question Yes, so what? With $\dot{¿} Y$ ?, in Spanish, instead of using a phrase with the same number of words, ¿Sí, $y$ qué?.

12. Literal translation.

To translate a word or an expression word for word, e.g., They are as like as two peas as Se parecen como dos guisante, or, She is reading as Ella está leyendo.

13. Modulation.

To change the point of view, focus or cognitive category in relation to the ST; it can be lexical or structural, e.g., to translate as you are going to have a child, instead of, you are going to be a father.

14. Particularization.

To use a more precise or concrete term, e.g., to translate window in English as guichet in French.

15. Reduction.

To suppress a ST information item in the TT, e.g., the month of fasting in opposition to Ramadan when translating into Arabic.

16. Substitution (linguistic, paralinguistic).

To change linguistic elements for paralinguistic elements (intonation, gestures) or vice versa, e.g., to translate the Arab gesture of putting your hand on your heart as Thank you.

17. Transposition. 
To change a grammatical category, e.g., He will soon be back translated into Spanish as No tardará en venir, changing the adverb soon for the verb tardar, instead of keeping the adverb and writing: Estará de vuelta pronto.

18. Variation.

To change linguistic or paralinguistic elements (intonation, gestures) that aspects of linguistic variation: changes of textual tone, style, social dialect, geographical dialect, etc., e.g., to introduce or change dialectal indicators for characters when translating for the theater, changes in tone when adapting novels for children, etc.

\subsection{Quality of Translation}

To rate the quality of translation, the researchers applied accuracy and acceptability rates offered by Nababan. Accuracy is a term used in evaluating translation to determine whether SL and TL have corresponded or not. The corresponding concept aims at the equivalence of both messages. A text is called as a message when it has the same meaning or the same message with other source text. Acceptability refers to a term whether a translation has already been expressed and appropriate with principles, norms and cultures which are prevailed in TL or not both in the level of macro and micro. The concept of acceptability becomes more important though the result of translation is accurate from the aspects of its contain and message. The translation will be refused by target readers when it is expressed contradictory with principles, norms and cultures of TL. (Nababan 2012: 44 - 45).

\section{Method}

The research applied qualitative descriptive method. The method was used to emphasize note with sentences in a detail, complete and exhaustively description defining the real situation to support the presentation of data (Sutopo, 2006: 40). Meanwhile, the approach used is theory of translation related to the quality of translation.

\subsection{Source of Data}

There are two sources of data in the research; English Translated Ads in Sukabumi and informants. The informants were chosen by certain criteria, namely those who are expert in translation filed.

\subsection{Technique of Collecting Data}

The technique of collecting data in the research is content analysis and questionnaire. First, the researcher had documentation by taking pictures of each ads. The location is in the area of Sukabumi (municipalities and districts). The obtained data were then sorted based on place, product and its TL.

The second technique, questionnaire, is applied with the aim to obtain information as a consideration to analyze the data in the form of opinions or views in assessing the quality of the translation ads. 


\section{MlMacrothink}

\subsection{Validity of Data}

Validity of data is aimed at obtaining the degree of accuracy and reliable data in research. Data validity technique used is technique of data source. The results of questionnaires from the raters added with the results of researcher's questionnaire can be used as a measuring tool to achieve the expected research objectives. Thus, the technique of data validity applied is validity technique of data source.

Assessment of questionnaire results is calculated to obtain a percentage of the value of accuracy and acceptability so that the translation quality of the data can be easily identified.

\subsection{Technique of Data Analysis}

Data analysis was done by using inductive analysis technique. This type of technique begins with collecting data, developing theories, or guesses, testing the validity of data that ultimately gets the answer from the problem as the final conclusion. While the analysis component used in this research is data reduction, data presentation, and conclusion drawing conclusion as well as verification (Sutopo, 2006: 88). Data reduction is done by selecting data. The data obtained are selected based on English advertising which is the result of translation only. In the data presentation, it was done by describing the data in narrative containing a series of systematic phrases. The data obtained were classified based on the use of translation techniques and the assessment from the informants. Then, from the result of the analysis, conclusion was drawn. Verification was done by the researcher if it is still found conclusions that are still considered to be doubtful.

\section{Result}

The analysis description of "Quality of English Advertisement Translation Technique in Sukabumi" is arranged based on the problems of statement. First, it is explained about what techniques are used by the ads translator. Then proceed with the quality of the ads translation as well as giving an alternative improvement to the translation results.

The researchers perform coding and presenting the data before finally analyzing and discussing it. This is done to make it easier to understand.

Data encoding is done by taking the initials of each data based on translation techniques both from SL and from TL. Here is an example of the encoding and its explanation. Code SL.TAm.110.a; "SL" means the SL, and "Tam" indicates the type of translation technique. In this case "Tam" means "Teknik Amplifikasi" (amplification technique). The number "110" denotes data 110 and the letter "a" refers to data that has more than one type of translation technique in a single data.

\subsection{Translation Technique}

In the analysis of translation technique, the researchers applied 18 translation techniques offered by Molina and Albir. Of the 101 ads there are 134 data. The data consists of words, phrases and sentences. The followings are the data analysis for translation techniques. 


\section{Adaptation}

The following is number of datum included in adaptation techniques is SL.TAd.85/TL.Tad.88, :

SL : Membuang racun pada tubuh anda (Banishing detox from your body).

TL : Detox your body.

The datum is found the ads of healthy product in the area of Cikole Sukabumi. The translator used the technique to change the cultural elements from SL into TL with the elements of culture that has any similarity in TL, it is "detox". Besides, the word is also familiar with the readers of SL. Of whole data, the use of the technique only reaches $0.76 \%$.

\section{Amplification}

The use of the technique is $5.22 \%$. The technique is available in data code SL,Tam.30/TL.Tam.32. :

\section{SL : Layanan Medis (Medical Service)}

TL : Medical Home Care.

In the translation, the word "home" is added to clarify meaning in SL because the medical service is held at patient's house (home). The datum is found in a drug store on Suryakencana, st Sukabumi.

\section{Borrowing}

In the ads English translation in Sukabumi, it was found that there are some techniques of pure borrowing applied. One of which is the datum with code SL.TPB.83/TL.TPB.86.

SL : Harum Jaya, 3 langkah untuk solusi pembangunan.

TL : Harum Jaya, 3 one step solution for building.

The translator kept using "Harum Jaya" in TL. The technique was applied because it is a name of a store located in Cibatu area, regency of Sukabumi. In an ads, the name of a store or a brand is retained because when it is forced to be translated in TL, it will have failed translation, thus the meaning will not be well transferred. The use of the technique is $16.42 \%$. Meanwhile, the use of Naturalized borrowing is available in code SL.TNB.84/ SL.TNB.87:

SL : Nitrogen menjaga performa ban anda.

TL : Nitrogen keep the tire performance.

The text is found on an ads in the gas station of Cibaraja are, Cisaat. The word "performa" in SL is adjusted with the spelling in TL so it becomes "performance". It was done by translator to make the word is easily understood in TL. The use of the technique reaches 3.73\%.

\section{Calque}

The datum included into the technique is SL.TCq.45/TL.TCq.47 is:

\section{SL : Kamar Istimewa \\ TL : Special Rooms}

The words in ST are found in MaxOne Hotel ads which were translated literally but the grammatical construction was adapted into grammatical construction of TL. It was applied because both languages have different grammatical construction. Once the translation is forced applying word for word translation, then the meaning will be different. The result of its translation will be "room special" meanwhile it is "special rooms" translation which is acceptable in TL. The use of 
the technique reaches $8.21 \%$.

\section{Discursive Creation}

The technique is usually applied for translation titles of book, novel as well as film. There are only two data using the technique, namely the number data SL.TKD.11/TL.TKD11 and kode SL.TKD.95/TL.TKD.98;

SL : Acara khusus hari jadinya Kota Sukabumi (promosi) dapatkan diskon 20\%, 12.00-15.00 WIB, hanya menunjukan kartu identitas anda. Untuk pengiriman: 210 $175 / 226205$

TL : Special moment Anniversary Kota Sukabumi (Happy Hours) get discount 20\%, 12.00-15.00 WIB, Just show your Id Card. Delivery 210 175/226 205.

The translator translated the word "promosi" into "happy hours" because it is a special term used in entertainment venue. Such term means "low price” which is valid for certain hours so that it makes customers happy. The term was used by translator for it is more familiar in TL. The use of the technique reaches $1.49 \%$.

6. Established Equivalent

The datum applies such technique is the data with code SL.TPL.3/TL.TPL.3.

SL : Rasakan sensasi keren.

TL : Feel the cool sensation.

In the product of "Mokko Krem" in Supermall, it is found the word "cool". The word was used by the translator because it is commonly used in daily life though the word originally means "cold". The use of the technique is $6.722 \%$.

\section{Generalization}

The data code of SL.TG.21/TL.TG.21 is one of the samples using generalization technique.

\section{SL : Pesantren SMPIT Al Ittihad.}

TL : Boarding school Smpit Al Ittihad

The word "pesantren” is a special term which is only used in countries using Malay language, one of which is Indonesia. Therefore, it seems that such word is strange in TL. That is why the translator found the neutral equivalent in translating it. The use of this technique is $5.97 \%$. 8. Literal

The literal technique is used in some data, one of the data is the datum with code SL.TL.6/TL.TL.6:

\section{SL : Rasakan bedanya.}

TL : Taste the difference.

The datum was translated word for word. It was done by the translator because there are some data having similar structure of language between SL and TL. The use of the technique reaches $19.40 \%$.

\section{Modulation}

The datum of code SL.TM.17/TL.TM.19 shows the use of modulation technique:

SL : Gratis tas jinjing untuk 150 voucher pertama.

TL : Free Goodie Bag for First 150 voucher.

The word "tas jinjing" was translated into "goody bag”. The translator did not use the word "handbag" or "portable bag" because the bag meant here is special bag used for gift. In TL the term "goody bag" is commonly used for bag of which there are some gifts in it which will 
be given to a person or group of people as a gift or even as a promotion form of a product. Such technique was applied by the translator in order to change point of view so that the result of translation is more reasonable. The use of the technique reaches $17.40 \%$.

\section{Particularization}

The following datum (SL.TP,88/TL.TP.91) shows the use of particularization:

SL : Tunjukkan penampilanmu untuk memenuhi keinginan anda.

TL : Show up your fashion to recharge your passion.

The word "fashion" is a more special term in TL to show to performance. Such word is also more specific referring to something worn in our body. Since it is an ads of a fashion brand, then the translator applied the particularization technique. The use of the technique reaches $2.24 \%$.

\section{Reduction}

The reduction technique is found in some data, one of whih is the datum number SL.TR.103.a/TL.TR.106.b :

\section{SL : Jadilah orang yang pertama untuk mendapatkan berita baru.}

TL : Be the first to get updates and news.

The TL sentence is found in the ads of a course. It is "Ganesha Operation" located in Jl. R Syamsuddin, S. H. The translator used reduction technique to the word "orang”. The reduction does not affect the distortion of meaning. In TL, the word "first" in the context of the sentence refers to "orang", thus the explicit information in SL is made to be implicit in TL. The reduction technique in the data reaches $2.24 \%$.

\section{Transposition}

There are 14 data that applied transposition technique. One of which is the datum number SL.TT.26/TL.TT.57;

\section{SL : Segera dibuka.}

TL : Opening Soon.

The phrase "Segera dibuka" in SL is a passive voice text. The translator changed grammatical category from passive voice into active sentence (opening soon). It was done because the grammatical structure in SL does not have any similarity with the grammatical structure in TL. Once the translator kept translating the passive voice text into passive form too (immediately opened), then it will not be acceptable grammatically in TL. The use of this technique is $10.44 \%$.

From the analysis of translation technique above, it is found that from 18 (eighteen) techniques of translator, there are 12 (twelve) techniques applied by the translators and from 134 data which have been analyzed, the most technique applied is literal technique which reaches $19.40 \%$. It shows that the translator used the technique done by word for word translation of which it does not relate it to the context. It is natural to apply the technique as far as the result of translation is still based on the structure in TL and qualified by fulfilling the terms of quality of translation (accuracy and acceptability). However, it does not occur to the translator of English translation ads that most of the SL text translated into TL using literal technique does not meet the terms of translation quality. One of the examples is found in the datum with code SL.TL.1/TL.TL.1. The SL text "Kebahagiaan yang sesungguhnya adalah ketika berbagi” was translated into “ Happiness is real when shared”. 


\section{MInstitute Macrothin}

International Journal of Linguistics

ISSN 1948-5425

2017, Vol. 9, No. 5

The translation of the phrase does not convey the message in SL. The translation offered must be "the real happiness". The following table shows the technique

Table 1. The Use of Translation Technique

\begin{tabular}{|c|l|c|c|}
\hline Num. & Technique of Translation & Total & Percentage \\
\hline 1. & Adaptation & 1 & 0,76 \\
\hline 2. & Amplification & 7 & 5,22 \\
\hline 3. & Borrowing & & \\
& a. Pure Borrowing & 22 & 16,42 \\
& b. Naturalized Borrowing & 5 & 3,73 \\
\hline 4. & Calque & 11 & 8,21 \\
\hline 5. & Discursive Creation & 2 & 1,49 \\
\hline 6. & Established Equivalent & 9 & 6,72 \\
\hline 7. & Generalization & 8 & 5,97 \\
\hline 8. & Literal & 26 & 19,40 \\
\hline 9. & Modulation & 23 & 17.16 \\
\hline 10. & Particularization & 3 & 2,24 \\
\hline 11. & Reduction & 3 & 2,24 \\
\hline 12. & Transposition & 14 & 10,44 \\
\hline & & &
\end{tabular}

\subsection{Quality of Translation}

\subsubsection{Accuracy}

To identify the quality of a translation text, it can be seen from two aspects; accuracy and acceptability. The accuracy of English translation ads in Sukabumi is very low. Of 12 technique of translation applied, it is only $38.6 \%$ of the technique indicated to be accurate. Some of the messages in SL are not well conveyed in TL. Moreover, there are some words, phrase and sentences which were not translated commonly translated grammatically in TL as well as the unclear context.

Table 2. Rate of Accuracy

\begin{tabular}{|c|l|c|c|c|c|}
\hline \multirow{2}{*}{ No. } & Technique of Translation & \multicolumn{4}{|c|}{ Accuracy } \\
\cline { 3 - 6 } & & $\begin{array}{c}\text { Rater } \\
\mathbf{1}\end{array}$ & $\begin{array}{c}\text { Rater } \\
\mathbf{2}\end{array}$ & $\begin{array}{c}\text { Rater } \\
\mathbf{3}\end{array}$ & Average \\
\hline 1. & Adaptation & 1 & 0 & 0 & 1 \\
\hline 2. & Amplification & 5 & 0 & 1 & 1 \\
\hline 3. & Borrowing & & & & \\
& a. Pure Borrowing & 3 & 1 & 11 & 3 \\
& b. Naturalized Borrowing & 3 & 0 & 2 & 1 \\
\hline 4. & Calque & 2 & 4 & 3 & 2 \\
\hline 5. & Discursive Creation & 0 & 0 & 1 & 3 \\
\hline 6. & Established Equivalent & 15 & 1 & 6 & 1 \\
\hline
\end{tabular}




\begin{tabular}{|c|l|c|c|c|c|}
\hline 7. & Generalization & 2 & 1 & 3 & 3 \\
\hline 8. & Literal & 10 & 6 & 3 & 1 \\
\hline 9. & Modulation & 6 & 6 & 10 & 3 \\
\hline 10. & Particularization & 2 & 0 & 2 & 2 \\
\hline 11. & Reduction & 2 & 1 & 2 & 2 \\
\hline 12. & Transposition & 4 & 5 & 4 & 2 \\
\hline
\end{tabular}

\subsubsection{Acceptability}

The analysis of acceptability rate indicates that technique of translation applied is very low, it is $30.8 \%$. There are many awkward translated data. One of the examples of the data is the datum with code SL.TKD.11/TL.TKD11. In SL there is a sentence "Tersedia gedung pertemuan" which was translated into TL "Trial Room Available now". The awkward translation occurs in the word "pertemuan" (meeting) which was translated into "trial”. The message is not well conveyed because between "pertemuan" and "trial" words do not have any equivalence in meaning. They are two different words. Thus the correct translation should be "A meeting hall is available" or "A meeting room is available". The following is table of acceptability rate:

Table 3. Rate of Acceptability

\begin{tabular}{|c|l|c|c|c|c|}
\hline No. & Technique of Translation & \multicolumn{4}{|c|}{ Acceptability } \\
\cline { 3 - 6 } & & $\begin{array}{c}\text { Rater } \\
\mathbf{1}\end{array}$ & $\begin{array}{c}\text { Rater } \\
\mathbf{2}\end{array}$ & $\begin{array}{c}\text { Rater } \\
\mathbf{3}\end{array}$ & Average \\
\hline 1. & Adaptation & 1 & 0 & 0 & 1 \\
\hline 2. & Amplification & 1 & 2 & 1 & 2 \\
\hline 3. & Borrowing & & & & \\
& a. Pure Borrowing & 6 & 4 & 9 & 3 \\
\hline 4. & b. Naturalized Borrowing & 3 & 0 & 2 & 1 \\
\hline 5. & Dalque & 3 & 4 & 4 & 3 \\
\hline 6. & Established Equivalent & 14 & 1 & 7 & 1 \\
\hline 7. & Generalization & 1 & 2 & 3 & 3 \\
\hline 8. & Literal & 7 & 8 & 4 & 2 \\
\hline 9. & Modulation & 6 & 6 & 10 & 3 \\
\hline 10. & Particularization & 1 & 1 & 2 & 3 \\
\hline 11. & Reduction & 2 & 0 & 3 & 3 \\
\hline 12. & Transposition & 1 & 7 & 5 & 2 \\
\hline
\end{tabular}

\section{Discussion}

Of the analysis above, it shows that from 18 techniques of translation there are 12 technique applied by translators in the English Translation Advertisement in Sukabumi namely adaptation, amplification, pure borrowing, naturalized borrowing, calque, discursive creation, 
established equivalent, generalization, literal, modulation, particularization, reduction and transposition. The accuracy and acceptability rate of the translation technique use are very low of which the accuracy rate only reaches $38.6 \%$ while the acceptability rate is also only $30.8 \%$. The result shows that the company did not hire the real translator in translating its ads. Therefore, to have a qualified translation, it is suggested that a company choose the real translator who comprehends both SL and TL so that he/she could well convey the information of the product. Besides, the qualified translation of ads will be reached by the certain methods. The following are the methods the translators should consider;

1. The translator should have a deep interview with the company concerning the products so that the translator really understands the content of the ads.

2. The translator should be able to choose the right choice of words to make readers interested in reading the text even interested in buying the products.

3. The translator should choose the right technique of translation in translating ads.

\section{Acknowledgement}

The research is financed by Ministry of Research and Technology, Higher education (Kemenristek Dikti) 2017.

Thanks for Havid Ardi from Univeritas Negeri Pendidikan (UNP) Padang and Asrofi Nur Kholifah from Universitas Soedirman (Unsoed) Purwokerto as the raters of the research.

\section{References}

Ahmed, T. L. O. (2016). The Translation of Football Name in Arab Media dalam Translation Journal, XIX(1).

Dewi, I. (2015). Kreatifitas dalam Penerjemahan Iklan. Journal Probisnis, 8(9), 44-57.

George, E. B., dan Michael, A. B. (2013). Advertising and Promotion. USA: The McGraw-Hill Companies.

Ginting, N. F. H. (2011). Manajemen Pemasaran. Bandung: CV Yrama Widya.

Machali, R. (2009). Pedoman Bagi Penerjemah. Bandung: Mizan - Kaifa.

Molina, L., dan Albir, H. A. (2002). Translation Techniques Revisited: A Dynamic and Functionalist Approach. Meta, XLVII(4), 492-512.

Nababan, N., \& Sumardiono (2012). Pengembangan Model Penilaian Kualitas Terjemahan. Journal Kajian Linguistik dan Sastra, 24(1), 39-57. Surakarta: Universitas Sebelas Maret.

Sumarwan, U., Agus, D., Aviliari, H. C., Royke, S., Jusup, A. S., Rico, R. B., \& dan Sofyan, R. (2009). Pemasaran Strategik; Strategi untuk Pertumbuhan perusahaan dalam Penciptaan Nilai Bagi Pemenang Saham. Jakarta: Intiprimasindo.

Sutopo, H. B. (2006). Metodologi Penelitian Kualitatif Surakarta: Sebelas Maret University Press. 


\section{Macrothink}

\section{Glossary}

AEC : Asian Economic Community

Ads : Advertisement

SL : Source Language

TL : Target Language

ST : Source Text

TT : Target Text.

\section{Copyrights}

Copyright for this article is retained by the author(s), with first publication rights granted to the journal.

This is an open-access article distributed under the terms and conditions of the Creative Commons Attribution license (http://creativecommons.org/licenses/by/4.0/) 